Zeszyty Naukowe Szkoły Głównej Gospodarstwa Wiejskiego w Warszawie

Problemy Rolnictwa Światowego tom 18 (XXXIII), zeszyt 3, 2018: 36-48

DOI: 10.22630/PRS.2018.18.3.64

Piotr Bórawski $^{1}$, Krzysztof Zalewski ${ }^{2}$

${ }^{1}$ Uniwersytet Warmińsko-Mazurski w Olsztynie

${ }^{2}$ Wyższa Szkoła Agrobiznesu w Łomży

\title{
Czynniki kształtujące produkcję mleka w Polsce na tle UE
}

\section{Factors Shaping Milk Production in Poland vis-à-vis the European Union}

\begin{abstract}
Synopsis. W pracy analizie poddano produkcję mleka w Polsce oraz czynniki ją determinujące na tle UE. Z analiz wynika, że produkcja mleka w Polsce po akcesji do UE wzrosła. Przyczyn tego zjawiska należy upatrywać $\mathrm{w}$ zmianach, jakie zaszły na rynku mleka i związane były z integracją europejska, systemem kwotowania i dostosowaniu do standardów unijnych w zakresie dobrostanu zwierząt. W analizie wyników badań wykorzystano metody tabelaryczne, graficzne i opisowe. W pracy przeprowadzono analizę statystyczną, z której wynika, że głównym czynnikiem decydującym o produkcji mleka w Polsce jest kurs euro-złoty.
\end{abstract}

Słowa kluczowe: podaż, mleko, kraje UE

\begin{abstract}
In the paper the production of milk in Poland and factors shaping it was analyzed against the background of the EU. The analysis shows that milk production in Poland after EU accession increased. The reasons for this phenomenon should be seen in the changes that took place in the milk market and were related to European integration, the quota system and adaptation to EU standards in the field of animal welfare. The tabular, graphical and descriptive methods were used in the analysis of the results. A statistical analysis which was carried out in the work, shows that the Euro-PLN exchange rate is the main determining factor in milk production in Poland.
\end{abstract}

Key words: supply, milk, EU countries

JEL Classification: Q110, Q130, Q170

\section{Wstęp}

Rynek mleka należy do najważniejszych branż sektora rolno-żywnościowego w Polsce i na świecie. Szacuje się, że w 2015 roku w Polsce blisko 280 tys. gospodarstw rolnych zajmowało się produkcją mleka, a zakłady przetwórcze zatrudniały blisko 31 tys. osób. Pozytywny wpływ na rozwój rynku mleka ma eksport, którego dodatnie saldo w 2016 roku wyniosło ok. 2,1 mln ton, czyli około 0,7 mld EUR (Szajner, 2017b; Rynek mleka..., 2017).

Na rynku mleka w Polsce zachodzą zmiany, które są skutkiem transformacji gospodarczej, integracji europejskiej, dostosowania do standardów UE oraz kwotowania produkcji mleka. W mleczarstwie nastapiły procesy integracji związane z koncentracja produkcji mleka, likwidacją najmniejszych gospodarstw oraz inwestycjami poprawiającymi

\footnotetext{
${ }^{1}$ dr hab. prof. UWM, Katedra Agrotechnologii, Zarządzania Produkcją Rolniczą i Agrobiznesu UW-M w Olsztynie, ul. M. Oczapowskiego 8, 10-719 Olsztyn, e-mail: pboraw@uwm.edu.pl; https://orcid.org/0000-0002-6616-7140

2 mgr, e-mail: k.zalewski@websky.pl
} 
konkurencyjność gospodarstw mleczarskich i przedsiębiorstw przetwórczych (Szajner, 2017a; Seremak-Bulge i in., 2005).

Produkcja mleczarska - jako jedyna - podlegała w Unii Europejskiej ograniczeniom produkcyjnym tzw. kwotowaniu (Zimmermann, Heckelei, 2012; Huettel, Jongeneel, 2011). Prowadzona $\mathrm{w}$ latach siedemdziesiątych ubiegłego wieku polityka wysokich cen gwarantowanych na produkty rolne - mająca zachęcić rolników do pozostania na wsi doprowadziła w szybkim czasie do dużej nadprodukcji, głównie masła. Dlatego też, w 1984 roku, na poszczególne kraje członkowskie UE zostały nałożone limity produkcyjne. Kwoty mleczne objęły również polskich farmerów i przez 10 lat zmuszeni oni byli do funkcjonowania $\mathrm{w}$ systemie limitów produkcyjnych. Ostatecznie kwoty mleczne zlikwidowano w 2015 roku i mając tego świadomość, iż rynek produkcji mleka zostanie uwolniony główny strumień pomocowy Programu Rozwoju Obszarów Wiejskich na lata 2007-2013 skierowany został na wsparcie gospodarstw mleczarskich - tak, aby odpowiednio je wzmocnić i przygotować do konkurowania w warunkach rynkowych.

Przyjęty kierunek działań Unii Europejskiej po 2003 roku przyczynia się do głębszej liberalizacji rynku mleka i uzależnienia od sytuacji globalnej. Prowadzić to będzie do większej niestabilności na europejskim rynku mleka. Ceny mleka i produktów mlecznych w większym stopniu uzależnione będą od sytuacji na rynkach światowych (Parzonko, 2013). Tezę te potwierdza Wilkin (2009), który twierdzi, iż liberalizacja obrotów handlowych i otwieranie się rynku europejskiego na konkurencję globalną sprawia, iż ceny i dochody rolnicze na terenie UE będą coraz silniej determinowane sytuacją na rynku światowym i stopniem przygotowania rolnictwa krajów unijnych do efektywnej konkurencji na rynku. Stąd konieczność usprawnienia łańcuchów dostaw jako sposobów na poprawę konkurencyjności polskiego mleczarstwa, wydaje się bardzo uzasadniona.

Produkty mleczne mają charakter masowy i globalny. Oznacza to, że zmiany na rynkach światowych mają wpływ na rynek mleka w Polsce. Na cenę mleka na rynku krajowym wpływ ma konsumpcja mieszkańców krajów, które są importerami (Polscy producenci mleka na tle Europy, 2016).

Rynek mleka jest obarczony wieloma problemami, w tym zróżnicowaniem popytu na mleko i jego przetwory oraz silną konkurencją na rynkach światowych (Bórawski, 2016). Do ważnych problemów zaliczyć można zmienne wzorce konsumpcji oraz zróżnicowanie dochodów wśród producentów mleka w krajach UE (Czyżewski, Guth, 2016).

\section{Cel i metoda badań}

Głównym celem badań było określenie wielkości produkcji mleka na tle pozostałych krajów UE. Do celów szczegółowych zaliczono:

- rozpoznanie zmian w produkcji mleka w Polsce

- poznanie czynników kształtujących produkcję mleka.

Zakres merytoryczny obejmował analizę zmian pogłowia krów w Polsce, wydajności mlecznej krów, przestrzennego zróżnicowania produkcji mleka w Polsce oraz w krajach UE. W pracy analizie poddano materiały Instytutu Ekonomiki Rolnictwa i Gospodarki Żywnościowej - PIB w Warszawie. Badaniu poddano informacje na temat produkcji mleka w latach 2005-2017.

Do identyfikacji czynników mających wpływ na produkcję mleka w Polsce wykorzystano równanie regresji wielorakiej w postaci (Sobczyk, 2005): 


$$
\gamma_{i}=\beta_{o}+\sum_{j=1}^{K} \beta_{j} X_{i j}+\varepsilon_{i}
$$

gdzie:

$y_{i}-\mathrm{i}$ - ta obserwacja dla zmiennej objaśniającej $(\mathrm{i}=1,2, \ldots \mathrm{n})$.

$X_{i j}$ - i-ta obserwacja na j-tej zmiennej objaśniajacej należqcej do zbioru zmiennych

objaśniajacych,

$\boldsymbol{\beta}_{o}, \boldsymbol{\beta}_{j}$,- parametry strukturalne równania regresji

Produkcja mleka została opisana przy użyciu zmiennej, której zmienność charakteryzuje model (1):

$\mathrm{Y}_{1}$ - produkcja mleka w Polsce (tys. litrów),

Należy zaznaczyć, że jest to metoda, która pozwala na określenie wpływu zmiennych egzogenicznych (objaśniających) na zmienną endogeniczną (objaśniana). Natomiast zmienne objaśniające model zostały dobrane przy uwzględnieniu przesłanek merytorycznych i stanowily je:

$\mathrm{X}_{1}$ - kurs euro,

$\mathrm{X}_{2}$ - ceny płacone rolnikom za mleko w Polsce,

$\mathrm{X}_{3}$ - ceny płacone rolnikom za mleko w UE,

$\mathrm{X}_{4}$ - indeks światowych cen mleka według FAO;

$\mathrm{X}_{5}$ - saldo handlu zagranicznego produktami mleczarskimi (mln EUR).

Chociaż nie są to jedyne zmienne wpływające na produkcję mleka w Polsce to ich dobór został podyktowany dostępnością danych. W okresie podanym analizą występowały kwoty mleczne, które regulowały produkcję mleka w Polsce. Były to jednak regulacje unijne, które nie były wynikiem oddziaływania sił rynkowych.

\section{Wyniki badań}

Istnieje wiele czynników kształtujących produkcję mleka w kraju. Jednym z nich jest kurs EUR, który definiuje się jako cenę jednostki pieniężnej innego kraju (w naszym przypadku krajów strefy EURO) wyrażoną w walucie krajowej (Samuelson, Nordhaus, 1996). W badanym okresie kurs EUR kształtował się na wysokim poziomie, co mogło być zachętą do eksportu artykułów mleczarskich i produkcji mleka w Polsce (tab.1).

Kolejnym czynnikiem zachęcającym do produkcji mleka w Polsce są ceny płacone rolnikom. W Polsce po okresie zniesienia kwot mlecznych nastąpił spadek cen a następnie ich wzrost, co w dużej mierze zależało od koniunktury na rynkach światowych (Bórawski, 2015).

Produkcja mleka w Polsce uległa zwiększeniu z 11905 tys. litrów w 2005 do 13314 tys. litrów w 2017 (rys. 1). Wzrost produkcji mleka w Polsce był pokłosiem zmian jakie miały miejsce na rynku.

Ważnym czynnikiem jest eksport, jak i import produktów mleczarskich, który wpływa na wysokość produkcji mleka w Polsce. Handel zagraniczny przetworami mleczarskimi wykazywał również tendencje wzrostowe po integracji Polski z UE. W latach 2003-2005 eksport rósł w średnim tempie 54\%, a import 48\% (Pietrzak, Szajner, 2006). Jak podają Stańko i Mikuła (2018) udział mleka i jego przetworów w handlu zagranicznym w eksporcie wynosił w 2000 roku 8,9\%, a w $2016-6,8 \%$, natomiast w imporcie odpowiednio wynosił $2,9 \%$ i $4,7 \%$. Saldo handlu zagranicznego mlekiem i jego przetworami było 
dodatnie i wzrosło z 154,7 mln EUR w 2000 roku do 691,7 mln EUR w roku 2016 (czyli wzrost o $347 \%$ ).

Tabela 1. Uwarunkowania rynkowe produkcji mleka w Polsce w latach 2005-2016

Table 1. Market conditions of milk production in Poland in the years 2005-2016

\begin{tabular}{|c|c|c|c|c|c|c|c|c|c|c|c|c|}
\hline Wyszczególnienie & 2005 & 2006 & 2007 & 2008 & 2009 & 2010 & 2011 & 2012 & 2013 & 2014 & 2015 & 2016 \\
\hline $\begin{array}{l}\text { Produkcja mleka } \\
\text { w Polsce (tys. t) }\end{array}$ & 11905 & 11974 & 12088 & 12418 & 12439 & 12270 & 12405 & 12659 & 12718 & 12986 & 13236 & 13244 \\
\hline Kurs euro (zl) & 4,0373 & 3,8952 & 3,7829 & 3,5166 & 4,3273 & 3,9946 & 4,1198 & 4,1969 & 4,2033 & 4,1847 & 4,1848 & 4,3757 \\
\hline $\begin{array}{l}\text { Ceny płacone } \\
\text { rolnikom za mleko } \\
(\text { EUR } / 100 \mathrm{~kg})\end{array}$ & 24,9 & 25,4 & 29,6 & 0,3 & 22,2 & 27,3 & 29,5 & 28,8 & 31,8 & 32,3 & 27,8 & 26,0 \\
\hline w UE (27/28) & 28,9 & 28,2 & 31,3 & 33,9 & 26,3 & 30,4 & 33,9 & 32,6 & 36,4 & 37,3 & 30,8 & 28,4 \\
\hline $\begin{array}{l}\text { Indeks światowych } \\
\text { cen mleka według } \\
\text { FAO }\end{array}$ & 123,7 & 120,9 & 130,8 & 160,7 & 141,3 & 158,3 & 183,3 & 182,0 & 184,1 & 198,3 & 168,1 & 156,2 \\
\hline $\begin{array}{l}\text { Saldo handlu } \\
\text { zagranicznego } \\
\text { produktami } \\
\text { mleczarskimi } \\
\text { (mln EUR) }\end{array}$ & 752,7 & 748 & 866,4 & 889 & 633 & 777,8 & 874,4 & 911,6 & 1017,5 & 1108,1 & 856,5 & 691,7 \\
\hline
\end{tabular}

Źródło: opracowania własne na podstawie IERiGŻ-PIB w Warszawie oraz Roczników Statystycznych Rolnictwa.

Kolejnym czynnikiem, który miał wpływ na rozwój produkcji mleka w Polsce był rozwój eksportu produktów rolno-spożywczych. W 2015 roku światowy eksport wzrósł o $1,9 \mathrm{mln}$ ton w ekwiwalencie mleka surowego do poziomu 74,1 mln ton. Głównym motorem wzrostu były niskie ceny produktów, co zachęciło do większych zakupów ze strony krajów rozwijających się gospodarczo. Wyjątkiem były Chiny, które zmniejszyły zakupy mleka w proszku o połowę, destabilizując tym działaniem cały sektor. Zmniejszone zamówienia ze strony Chin wywołały nadwyżkę mleka w proszku na rynku, co odbiło się bezpośrednio na indeksie cen produktów mlecznych (Seremak-Bulge, 2015).

Produkcja mleka w Polsce jest uzależniona również od wielkości spożycia mleka, które średnio w UE uległo zmniejszeniu w latach 2005-2010 z 288,5 kg/mieszkańca do 280 $\mathrm{kg} /$ mieszkańca (Bórawski, 2015). Na terenie UE spadek spożycia mleka był jedną z przyczyn zwiększenia eksportu produktów mleczarskich (Seremak-Bulge, Bodył, 2014).

Wzrost produkcji mleka był wynikiem wielu zmian, m.in. przeprowadzonych procesów restrukturyzacyjnych, dostosowań do standardów UE dotyczących bezpieczeństwa zdrowotnego żywności oraz dostępu do wspólnego rynku, gdzie konsumenci posiadają dużą siłę nabywczą (Urban, 2004; Rembeza, Seremak-Bulge, 2009; Szajner, 2017a). Wejście Polski do Unii Europejskiej otworzyło przed polskimi rolnikami nowe możliwości pozyskania wsparcia finansowego na inwestycje w gospodarstwach rolnych, co z kolei przełożyło się na permanentne zwiększanie wydajności mlecznej krów. Ciaggłe zwiększanie produkcji mleka to także efekt dobrej koniunktury na mleko na rynkach światowych i wysokich cen na jego przetwory - głównie masło w latach 2017 i 2018.

Sprzyjającym czynnikiem w produkcji mleka w Polsce jest racjonalne wykorzystanie łąk i pastwisk. Podstawową bazę paszową w Polsce stanowią użytki zielone ze względu na niskie koszty produkcji jednostki pokarmowej (Olszewska, 2015). 
Wielkość pogłowia bydła w Polsce wykazuje tendencję rosnącą. W roku 2005 wynosiła ok. 5,5 mln sztuk, zaś na koniec 2017 roku przekroczyła wartość 6 mln sztuk. Tym samym w ciagu 12 lat (lata 2005-2017) liczebność bydła w Polsce wzrosła o ponad pół miliona sztuk. Liczebność krów pokazuje nieco odmienny trend. W latach $2005-2017$ liczba krów systematycznie spadała. W roku 2005 krów w Polsce było 2,8 mln sztuk, zaś w roku 2017 blisko $0,8 \mathrm{mln}$ mniej - bo 2 mln sztuk. (rys. 1). W UE w 2017 roku odnotowano spadek pogłowia krów o około 1\% w porównaniu do roku 2016 i jego liczba była zbliżona do roku 2011 i wynosiła 23,1 mln sztuk (Produkcja mleka i pogłowie krów w Unii Europejskiej http://nowypm.pl).

Z kolei wydajność mleczna krów w latach 2005-2017 wzrosła z 4213 do 6330 litrów/sztukę. Wśród czynników, które zdecydowały o wzroście wydajności krów mlecznych wymienia się postęp biologiczny w hodowli oraz postęp techniczny w zakresie żywnie i utrzymania bydła (Ziętara, 2007).



Rys. 1. Pogłowie, produkcja i wydajność mleczna krów w Polsce w latach 2005-2017

Fig. 1. Heads of cows, production and milk yields in Poland in the years 2005-2017

Źródło: Opracowania własne na podstawie Rynek mleka stan i perspektywy. Instytut Ekonomiki Rolnictwa i Gospodarki Żywnościowej-PIB, ARR, Ministerstwo Rolnictwa i Rozwoju Wsi 2017.

$\mathrm{Na}$ uwagę zasługuje także utrzymujący się spadek udziału krów mlecznych w pogłowiu bydła ogółem $(36,1 \% \mathrm{w}$ grudniu 2016 r. wobec $37,0 \% \mathrm{w}$ grudniu 2015 r. i 52,5\% w grudniu 2004 r.). Odzwierciedla on rosnące zainteresowanie hodowlą bydła mięsnego w Polsce, przy jednoczesnej coraz wyższej wydajności produkcji mleka. Prognozowany dalszy wzrost cen mleka oraz cen skupu żywca wołowego będzie oddziaływać w kolejnych kwartałach w kierunku dalszego wzrostu pogłowia bydła w Polsce (www.credit-agricole.pl).

W Polsce dominują gospodarstwa małe - utrzymujące do 10 krów. Stanowią one $75 \%$ ogółu gospodarstw (rys. 2). Gospodarstwa utrzymujące do 10 krów mają ograniczone możliwości rozwoju ze względu na małą skalę produkcji oraz produkcję na rynek i 
częściowo na samozaopatrzenie. Słaby kontakt $\mathrm{z}$ rynkiem tych gospodarstw powoduje bierne zachowania ich właścicieli do zmian otoczenia (Kasztelan, 2010).

Gospodarstw utrzymujących powyżej 50 krów dojnych jest w Polsce zaledwie 3\%. Szczegółowe zestawienie ukazuje rysunek 2. Jak podają Czyżewski i Śmigla (2012) tylko gospodarstwa średnie i duże mają szanse na restrukturyzację produkcji mleka, która powinna skutkować poprawą efektywności.

W zakresie liczby gospodarstw zajmujących się produkcją mleka zachodzą zmiany. W roku 2002 gospodarstw posiadających do 10 krów było w Polsce 819,2 tys., a w 2016262,6 tys. (czyli spadek o 68\%). Z kolei gospodarstw utrzymujących powyżej 10 krów było w 2002 roku 56,2 tys., a w roku 2016 - 85,4 tys. (czyli wzrost o 52\%) (Ziętara, 2010; Rynek mleka..., 2017).

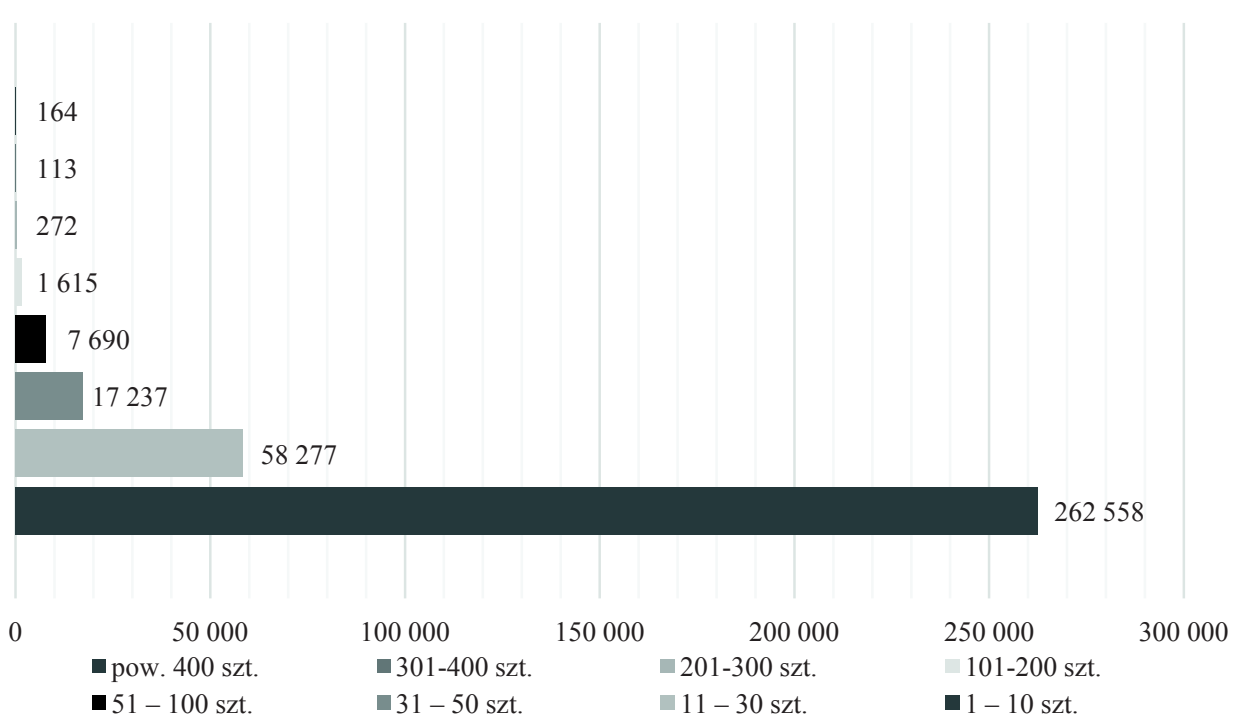

Rys. 2. Liczba siedzib stad utrzymujących krowy w Polsce w 2016 roku

Fig. 2. The number of residences of herds keeping cows

Źródło: Opracowania własne na podstawie Rynek mleka stan i perspektywy. Instytut Ekonomiki Rolnictwa i Gospodarki Żywnościowej-PIB, ARR, Ministerstwo Rolnictwa i Rozwoju Wsi 2016.

Produkcja oraz skup mleka w Polsce jest regionalnie zróżnicowana. Najwięcej krów mlecznych występuje w województwach: mazowieckim (19,9\% pogłowia) oraz podlaskim (18,4\% pogłowia), w których również odnotowuje się największą koncentrację krajowego przetwórstwa tego surowca. W przeliczeniu na 100 ha użytków rolnych największym pogłowiem charakteryzują się województwa podlaskie, a następnie mazowieckie, warmińsko-mazurskie oraz łódzkie (Wasilewski, 2009).

Badania na temat regionalnego zróżnicowania produkcji mleka w Polsce prowadził Parzonko (2013b). Z analiz autora wynika, że od 2004 roku produkcja mleka w Polsce sukcesywnie zwiększa się. Największe zwiększenie pogłowia krów i obsady w latach 20022010 miała miejsce $\mathrm{w}$ województwie podlaskim, warmińsko-mazurskim i północnej części województwa mazowieckiego. Z kolei największe zmniejszenie pogłowia w analogicznym 
okresie miało miejsce w województwie małopolskim i podkarpackim. Porównując wyniki badania Parzonki do obecnej sytuacji na rynku należy stwierdzić, że sytuacja kształtuje się podobnie. W czerwcu 2017 roku największą obsadą charakteryzowało się województwo podlaskie (41,0 krów mlecznych na 100 ha UR) oraz mazowieckie (24,2 na 100 ha UR).

Regiony rozwijające produkcję mleka w latach 2004-2010 według Parzonko (2013b) charakteryzowały się niższą jakością gleb i większym udziałem TUZ w strukturze UR $\mathrm{w}$ porównaniu do regionów ograniczających produkcję mleka. Ponadto $\mathrm{w}$ regionach rozwijających produkcję mleka średnia powierzchnia gospodarstwa była czterokrotnie większa niż w porównaniu do regionów ograniczających produkcję mleka.

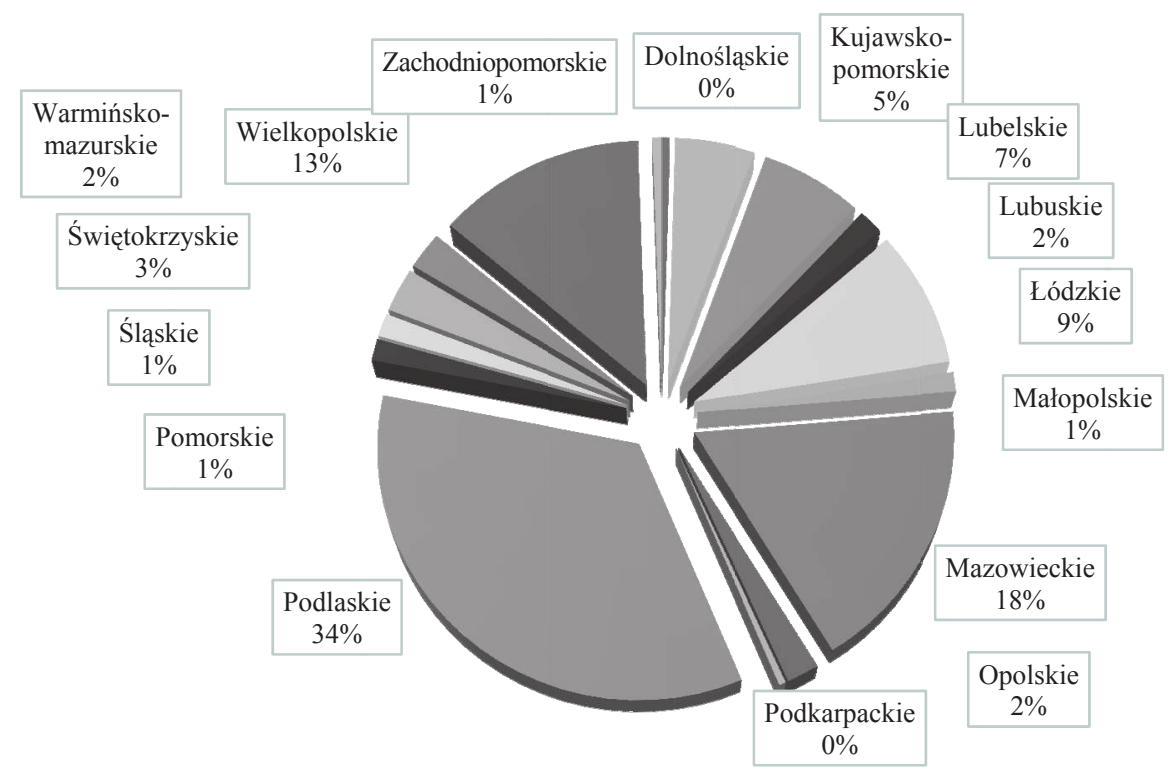

Rys. 3. Procentowy udział ilości skupowanego mleka w styczniu 2017 według siedziby jednostki skupującej

Fig. 3. Percentage share of the quantity of purchased milk in the period of 2017, according to the registered office of the purchasing entity

Źródło: opracowania własne na podstawie Rocznika Statystycznego Rolnictwa i Rozwoju Obszarów Wiejskich GUS 2018.

Z informacji zawartych na rysunku 3 wynika, że największy odsetek ilości skupowanego mleka odnotowano w styczniu 2017 roku w województwie podlaskim (34\%), mazowieckim (18\%) oraz wielkopolskim (13\%). Łącznie w tych trzech województwach w kraju w styczniu 2017 skupiono 65\% mleka. Dane wskazują na silną koncentrację skupu mleka w tych trzech województwach.

Analizując z kolei skup mleka w tysiącach litrów w styczniu 2017 roku według województw można zauważyć duże regionalne zróżnicowanie (rys. 4). Najmniej mleka w styczniu 2017 roku skupiono w województwie lubuskim (6 443 tys. litrów), podkarpackim (9 271 tys. litrów) oraz małopolskim (10 352 tys. litrów). Najwięcej mleka w styczniu 2017 roku skupiono w województwie podlaskim (197599 tys. litrów), mazowieckim (196 043 tys. litrów) oraz wielkopolskim (144 713 tys. litrów). 


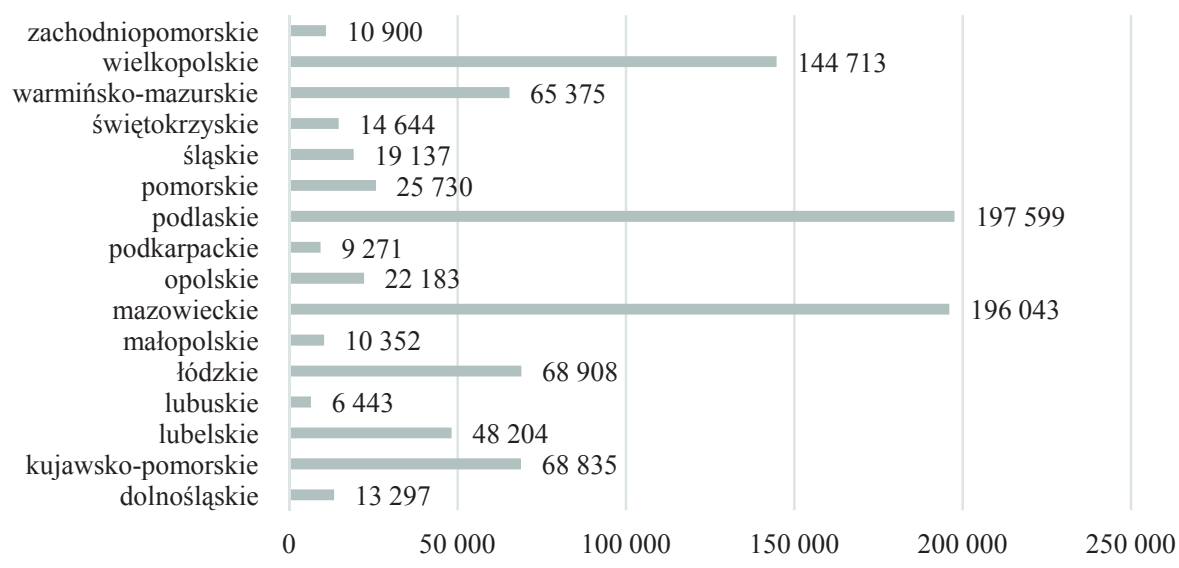

Rys. 4. Zestawienie ilości skupowanego mleka w styczniu 2017 roku w tys. litrów według siedziby producenta

Fig. 4. Summary of the amount of purchased milk in the period of 2017 , in thousand liters according to the manufacturer's headquarters

Źródło: opracowania własne na podstawie Rocznika Statystycznego Rolnictwa i Rozwoju Obszarów Wiejskich GUS 2018.

W tabeli 2 przedstawiono zmiany w produkcji mleka w roku $2016 \mathrm{w}$ porównaniu do 2007, zawartości tłuszczu i wykorzystaniu mleka w krajach UE. Z analiz wynika, że największą ilość wyprodukowanego mleka w 2007 roku odnotowano w Niemczech, Wielkiej Brytanii, Francji, Włoszech oraz Polsce. W roku 2016 największym producentem mleka w UE były Niemcy (32,7 mln t.), Francja (26,1 mln t.), Wielka Brytania (14,9 mln t.), Holandia (14,3 mln t.) oraz Polska (13,3 mln t.) i Włochy (12,7 mln t.) (Eurostat, 2017). W roku 2017 w UE wyprodukowano 165,4 mln ton i było to mniej o 1,5\% niż w $2016 \mathrm{r}$.

Analizując zawartość tłuszczu w mleku w krach UE można zauważyć, że największy wzrost zawartości tłuszczu w roku 2016 w porównaniu do 2007 odnotowano w Belgii (48,4\%), Rumunii (40,4\%) oraz na Litwie (32,5\%). Z kolei największy spadek zawartości tłuszczu w roku 2016 w porównaniu do 2007 odnotowano w Holandii $(-44,2)$, na Cyprze $(-22,4 \%)$ oraz w Portugalii $(-17,4 \%)$.

Oceniając z kolei wykorzystanie mleka w krajach UE należy stwierdzić, że największy wzrost w roku 2016 w porównaniu do 2007 odnotowano w Belgii (48,2\%), Rumunii $(37,9 \%)$ i Austrii $(27,7 \%)$. Z kolei największe zmniejszenie wykorzystania mleka w roku 2017 w porównaniu do 2007 odnotowano w przypadku Holandii (-44,7\%), Włoszech $(-9,9 \%)$ i Słowenii $(-5,6 \%)$.

Rysunek 5 przedstawia syntetyczny wskaźnik cen żywności FFPI (Fao Food Price Index) w korelacji do produktów mleczarskich. Według najnowszej metody FFPI uwzględnia 23 produkty. W metodzie tej stosuje się cenowy indeks Laspeyresa. Indeksy zespołowe (agregatowe) - pozwalają analizować zmiany wartości, cen oraz ilości zbioru (grupy produktów, wyrobów, artykułów), które nie są jednorodne. Indeks odzwierciedla ogólną zmianę cen pomiędzy okresem bazowym a bieżącym, gdzie wagi opierają się na strukturze wydatków $\mathrm{z}$ okresu bazowego, albo z okresu bieżącego. Wadą Indeksu Laspeyresa, bazującego na strukturze konsumpcji sprzed okresu badania, jest to, że może przeszacowywać rzeczywistą inflację (Hałka, Leszczyńska, 2011). W rezultacie wyliczeń 
otrzymujemy średnie indeksy dla najważniejszych grup produktów, t.j. zbóż, produktów mleczarskich, mięsa, cukru i olejów roślinnych.

Tabela 2. Produkcja mleka i produktów mleczarskich w Unii Europejskiej w 2007 i 2016 roku

Table 2. Production of milk and dairy products in the European Union in 2007 and 2016 year

\begin{tabular}{|c|c|c|c|c|c|c|c|c|c|}
\hline \multirow{3}{*}{ Wyszczególnienie } & \multicolumn{9}{|c|}{ Produkt naturalny (fresh product) } \\
\hline & \multicolumn{2}{|c|}{$\begin{array}{l}\text { Produkt uzyskany } \\
\qquad(1000 \mathrm{t})\end{array}$} & \multirow{2}{*}{$\begin{array}{c}\begin{array}{c}\text { Zmiany } \\
(\%)\end{array} \\
(\%)\end{array}$} & \multicolumn{2}{|c|}{ Zawartość tłuszczu (t) } & \multirow{2}{*}{$\begin{array}{c}\begin{array}{c}\text { Zmiany } \\
(\%)\end{array} \\
(\%)\end{array}$} & \multicolumn{2}{|c|}{$\begin{array}{l}\text { Wykorzystanie } \\
\text { mleka (1000 t) }\end{array}$} & \multirow{2}{*}{$\begin{array}{c}\begin{array}{c}\text { Zmiany } \\
(\%)\end{array} \\
(\%)\end{array}$} \\
\hline & 2007 & 2016 & & 2007 & 2016 & & 2007 & 2016 & \\
\hline Austria & $1,027.6$ & $1,184.3$ & 15,3 & $39,604.0$ & $50,301.8$ & 27,0 & 936.7 & $1,196.4$ & 27,7 \\
\hline Belgia & $1,398.1$ & $1,536.3$ & 9,9 & $59,584.7$ & $88,416.1$ & 48,4 & $1,462.5$ & $2,167.1$ & 48,2 \\
\hline Bułgaria & 197.9 & 215.6 & 8,9 & $5,655.1$ & $6,129.8$ & 8,4 & 156.0 & 166.8 & 6,9 \\
\hline Cypr & 98.2 & 81.3 & $-17,3$ & $3,784.2$ & $2,935.8$ & $-22,4$ & 88.9 & 72.1 & $-18,9$ \\
\hline Czechy & 913.1 & 898.2 & $-1,6$ & $27,320.0$ & $29,951.4$ & 9,6 & 704.1 & 791.8 & 12,5 \\
\hline Niemcy & $8,838.0$ & $8,685.6$ & $-1,7$ & $387,681.1$ & $429,694.8$ & 10,8 & $9,181.1$ & $9,695.1$ & 5,6 \\
\hline Dania & 809.4 & 829.6 & 2,5 & $30,405.8$ & $30,020.9$ & $-1,3$ & 714.6 & 693.0 & $-3,0$ \\
\hline Estonia & 160.2 & 172.6 & 7,7 & $9,821.7$ & $9,436.0$ & $-3,9$ & 236.4 & 227.6 & $-3,7$ \\
\hline Hiszpania & - & $5,025.1$ & - & $129,561.6$ & $143,406.8$ & 10,7 & $3,381.9$ & $3,893.7$ & 15,1 \\
\hline Finlandia & $1,006.2$ & 940.1 & $-6,6$ & $23,300.6$ & $25,492.4$ & 9,4 & 548.9 & 576.4 & 5,0 \\
\hline Francja & $6,434.1$ & $6,198.3$ & $-3,7$ & $214,220.7$ & $232,952.7$ & 8,7 & $5,134.4$ & $5,572.1$ & 8,5 \\
\hline Grecja & 251.5 & 686.5 & 172,9 & $24,239.0$ & $23,944.0$ & $-1,2$ & 614.0 & 611.1 & $-0,5$ \\
\hline Węgry & - & - & - & $30,163.1$ & $31,556.3$ & 4,6 & 822.6 & 862.1 & 4,8 \\
\hline Irlandia & 581.4 & - & - & - & $24,786.5$ & - & - & 599.2 & - \\
\hline Włochy & $3,368.4$ & $2,960.9$ & $-12,1$ & $116,877.0$ & $107,316.9$ & $-8,2$ & $3,141.9$ & $2,831.6$ & $-9,9$ \\
\hline Litwa & 184.6 & 212.6 & 15,2 & $15,334.4$ & $20,313.8$ & 32,5 & 365.1 & - & - \\
\hline Luksemburg & - & - & - & - & - & - & - & - & - \\
\hline Łotwa & - & - & - & $10,790.6$ & $12,237.6$ & 13,4 & 230.1 & 320.8 & 39,4 \\
\hline Chorwacja & 448.9 & - & - & $17,360.5$ & $16,305.4$ & $-6,1$ & 493.9 & 502.5 & 1,7 \\
\hline Malta & 33.4 & - & - & 822,4 & - & - & 32.2 & - & - \\
\hline Holandia & - & - & - & $34,981.2$ & $19,515.0$ & $-44,2$ & 788.7 & 436.0 & $-44,7$ \\
\hline Polska & $2,182.7$ & $2,627.4$ & 20,4 & $94,707.6$ & $112,843.9$ & 19,1 & $2,383.5$ & $2,779.6$ & 16,6 \\
\hline Portugalia & - & - & - & $23,965.7$ & $19,791.9$ & $-17,4$ & $1,092.6$ & 918.7 & $-15,9$ \\
\hline Rumunia & - & - & - & $18,165.6$ & $25,503.2$ & 40,4 & 490.6 & 676.5 & 37,9 \\
\hline Słowacja & 347.1 & - & - & $11,705.6$ & $13,231.3$ & 13,0 & 317.6 & 378.8 & 19,2 \\
\hline Słowenia & - & - & - & $9,422.4$ & $8,918.5$ & $-5,3$ & 229.4 & 216.5 & $-5,6$ \\
\hline Szwecja & $1,296.8$ & $1,142.9$ & $-11,9$ & $48,540.5$ & $55,465.2$ & 14,3 & $1,14.5$ & $1,320.6$ & 15,1 \\
\hline W. Brytania & $7,643.6$ & $8,041.8$ & 5,2 & $291,879.0$ & $287,664.4$ & $-1,4$ & $7,185.2$ & $6,984.9$ & $-2,8$ \\
\hline
\end{tabular}

Źródło: opracowania własne na podstawie Rynek mleka stan i perspektywy. Instytut Ekonomiki Rolnictwa i Gospodarki Żywnościowej-PIB, ARR, Ministerstwo Rolnictwa i Rozwoju Wsi 2016.

Zauważalne są wyraźne wzrosty cen przetworów mlecznych, co można tłumaczyć wysokim zapotrzebowaniem na rynkach azjatyckich (Baer-Nawrocka i inni, 2012). Najwyższą wartość wskaźnika cen mleka odnotowano w roku 2013 (242,7) oraz 2014 $(224,1)$. W kolejnych dwóch latach wskaźnik zaczął maleć, po czym w roku 2017 wzrósł 
do 202,2. Wskaźnik światowych cen mleka w latach 2000-2017 uległ znacznym zmianom, co miało wpływ na produkcję mleka w Polsce i na świecie.

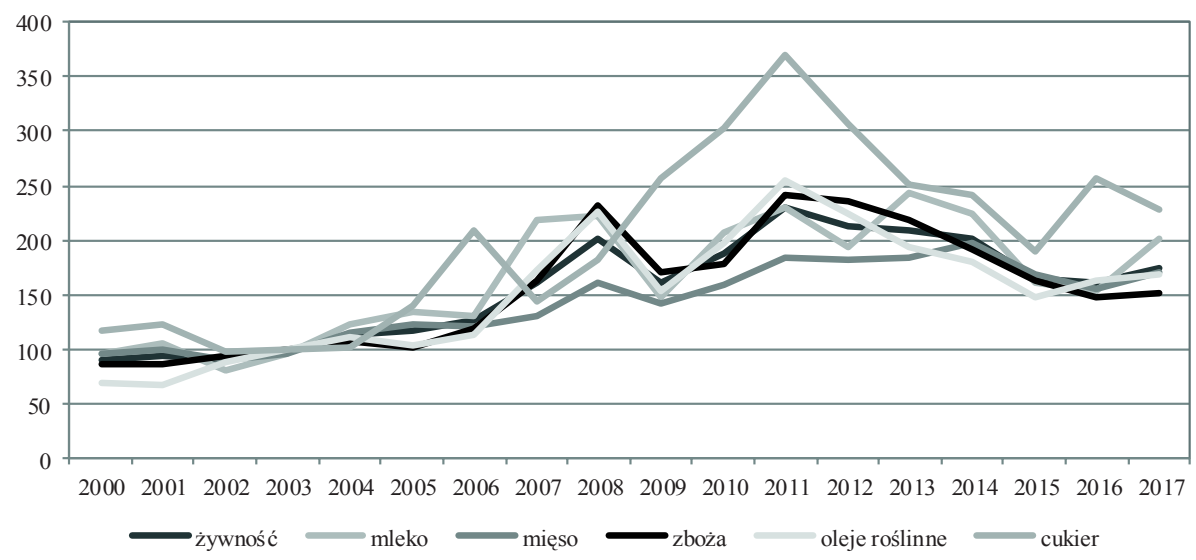

Rys. 5. Wskaźnik światowych cen żywności FAO w latach 2000-2017

Fig. 5. FAO index of global food prices in 2000-2017

Źródło: FAO Food Index Price http://www.fao.org/worldfoodsituation/foodpricesindex/en/ 24.08.2018.

W pracy analizie poddano zależności między zmiennymi objaśniającymi produkcje mleka w Polsce. Miernikiem zależności między zmiennymi jest współczynnik korelacji, który przyjmuje wartości od -1 do 1 . Gdy współczynnik wynosi 0 oznacza to, że nie ma korelacji między zmiennymi. Dodatni współczynnik korelacji oznacza wzrost obu cech, zaś ujemny wzrost jednej cechy i spadek innej (Bórawski 2015). W analizie zastosowano pięć zmiennych wpływających (egzogenicznych): $\mathrm{X}_{1}$-kurs euro, $\mathrm{X}_{2}$-ceny płacone rolnikom za mleko w Polsce, $\mathrm{X}_{3}$-ceny płacone rolnikom za mleko w UE, $\mathrm{X}_{4}$-indeks światowych cen mleka według FAO; $\mathrm{X}_{5}$-saldo handlu zagranicznego produktami mleczarskimi (mln EUR). Dobór zmiennych opierał się na kryteriach merytorycznych oraz dostępności danych.

Tabela 3 Wyniki korelacji między zmiennymi objaśniającymi

Table 3 . The results of the correlation between the explanatory variables

\begin{tabular}{l|ccccc}
\hline \multicolumn{1}{c|}{ Wyszczególnienie } & $\begin{array}{c}\mathrm{X}_{1} \text { (kurs } \\
\text { euro) }\end{array}$ & $\begin{array}{c}\mathrm{X}_{2} \text { (ceny płacone } \\
\text { rolnikom za mleko } \\
\text { w Polsce) }\end{array}$ & $\begin{array}{c}\mathrm{X}_{3} \text { (ceny płacone } \\
\text { rolnikom za mleko } \\
\text { w UE) }\end{array}$ & $\begin{array}{c}\mathrm{X}_{4} \text {-indeks } \\
\text { światowych } \\
\text { cen mleka } \\
\text { według FAO }\end{array}$ & $\begin{array}{c}\mathrm{X}_{5} \text {-saldo handlu } \\
\text { zagranicznego prod. } \\
\text { mleczarskimi } \\
\text { (mln EUR) }\end{array}$ \\
\hline $\begin{array}{l}\mathrm{X}_{1} \text { (kurs euro) } \\
\mathrm{X}_{2} \text { (ceny płacone rolnikom } \\
\text { za mleko w Polsce) }\end{array}$ & 1,000 & $-0,260$ & $-0,145$ & 0,332 & $-0,119$ \\
$\begin{array}{l}\mathrm{X}_{3} \text { (ceny płacone rolnikom } \\
\text { za mleko w UE) }\end{array}$ & $-0,260$ & 1,000 & 0,962 & 0,706 & 0,939 \\
$\begin{array}{l}\mathrm{X}_{4}-\text { indeks światowych cen } \\
\text { mleka według FAO }\end{array}$ & $0,0,145$ & 0,962 & 1,000 & 0,794 & 0,964 \\
$\begin{array}{l}\mathrm{X}_{5}-\text { saldo handlu } \\
\text { zagranicznego produktami } \\
\text { mleczarskimi (mln EUR) }\end{array}$ & $-0,119$ & 0,706 & 0,794 & 1,000 & 0,7338 \\
\hline
\end{tabular}

Źródło: obliczenia własne na podstawie Rynek mleka..., 2017. IERiGŻ-PIB w Warszawie. 
Ceny płacone rolnikom za mleko $\mathrm{w}$ Polsce były silnie skorelowane $\mathrm{z}$ cenami płaconymi rolnikom za mleko w UE, indeksem światowych cen FAO oraz saldem handlu zagranicznego produktami mleczarskimi (tab. 3). W celu pominięcia efektu takiego samego wpływu dwóch i większej liczby zmiennych dokonano eliminacji z modelu najbardziej skorelowanych ze sobą zmiennych. Dlatego $\mathrm{w}$ analizie przyjęto do modelu regresji wielorakiej następujące zmienne: kurs euro, ceny płacone rolnikom za mleko w Polsce i w UE oraz saldo handlu zagranicznego produktami mleczarskimi.

Tabela 4. Wyniki regresji liniowej pomiędzy zmienną zależną produkcja mleka w Polsce a zmiennymi niezależnymi

Table 4. Results of regression between the dependent change in milk production in Poland and independent variables

\begin{tabular}{|c|c|c|c|c|}
\hline Wyszczególnienie & Współczynnik & Błąd standardowy & t-studenta & Wartość p \\
\hline $\mathrm{X}_{1}$ (kurs EUR) & 1512,41 & 524,80 & 2,88 & 0,024 \\
\hline $\begin{array}{l}\mathrm{X}_{2} \text { (ceny płacone rolnikom za mleko } \\
\text { w UE) }\end{array}$ & 222,10 & 155,54 & 1,428 & 0,196 \\
\hline $\begin{array}{l}\mathrm{X}_{3} \text { (ceny płacone rolnikom za mleko } \\
\text { w UE) }\end{array}$ & $-96,57$ & 160,94 & $-0,600$ & 0,567 \\
\hline $\begin{array}{l}\mathrm{X}_{5} \text {-saldo handlu zagranicznego } \\
\text { produktami mleczarskimi (mln EUR) }\end{array}$ & $-1,01$ & 3,23 & $-0,313$ & 0,764 \\
\hline
\end{tabular}

Źródło: obliczenia własne.

Dotychczas badano jak czynniki determinujące salda obrotów artykułami mleczarskimi korelowały ze sobą. Za ważne uznano jednak zbadanie wpływu czynników opisujących produkcję mleka w Polsce wykorzystując równanie regresji liniowej (tab. 4). Stosując regresję wieloraką stwierdzono, że w wyniku przeprowadzonej analizy produkcja mleka w Polsce zależała od $\mathrm{X}_{1}$ (kursu EUR). Współczynnik determinacji $\mathrm{R}^{2}$ był dość wysoki i osiagnął wartość 0,58 co oznacza średnie dopasowanie modelu.

\section{Podsumowanie i wnioski}

Polska jest ważnym producentem mleka w UE i zajmuje 5 miejsce po Niemczech, Francji, Wielkiej Brytanii i Włoszech. Polska w światowej produkcji mleka zajmuje 12 miejsce. Utrzymanie pozycji ważnego producenta mleka w UE wymaga nakładów inwestycyjnych zarówno w gospodarstwach mleczarskich, jak i w przemyśle przetwórczym.

Z przeprowadzonej analizy wynika, że produkcja mleka w Polsce zależała głównie od zmiennej $\mathrm{X}_{1}$ (kurs EUR). W latach 2005-2016 kurs EUR kształtował się na korzystnym wysokim poziomie, co zachęcało do eksportu produktów mleczarskich i produkcji mleka w Polsce.

Na rynku mleka zaszło wiele zmian szczególnie po roku 2004 i związane one były z wprowadzeniem, a później likwidacją systemu kwotowania oraz dostosowaniem do standardów i wymogów UE.

Od momentu wejścia Polski do UE odnotowano wzrost produkcji mleka, spadek pogłowia krów i wzrost wydajności mlecznej krów. Było to spowodowane szeregiem czynników, między innymi podobnymi tendencjami w pozostałych krajach UE i na świecie.

W Polsce występuje duże terytorialne zróżnicowanie w produkcji mleka. Dominującą pozycję zajmują województwa podlaskie, mazowieckie i wielkopolskie. Również w zakresie 
skupu mleka województwa podlaskie, mazowieckie i wielkopolskie zajmują dominującą pozycję i skupiono w nich w 2016 roku odpowiednio 34\%, 18\% i 13\% w skali kraju.

Pod względem liczby gospodarstw produkujących mleko dominują w Polsce podmioty posiadające do 10 krów. Jednak ich liczba w latach 2002-2016 uległa zmniejszeniu o 68\%. Równocześnie odnotowano w analogicznym okresie wzrost liczby gospodarstw posiadających pow. 10 krów z 56,2 tys. do 95,4 tys. (wzrost o 52\%).

\section{Literatura}

Baer-Nawrocka, A., Grochowska, R., Kiryluk-Dryjska, E., Seremak-Bulge, J., Szajner, P. (2012). Światowy rynek mleka i jego wpływ na polskie mleczarstwo po zniesieniu kwot mlecznych (The global milk market and its impact on Polish dairy industry after the abolition of milk quotas), IERiGŻ-PIB, Warszawa, s. 113-114.

Bórawski, P. (2016). Recenzja książki Andrzeja Czyżewskiego i Marty Guth: Zróżnicowanie produkcji mleka w makroregionach Unii Europejskiej z wyróżnieniem Polski (Review of the book by Andrzej Czyżewski and Marta Guth: Diversification of milk production in macro-regions of the European Union with the distinction of Poland). Zagadnienia Ekonomiki Rolnej 4(349), 162-167.

Bórawski, P. (2015). Tendencje w handlu zagranicznym polskiego sektora mleczarskiego (Tendencies in international trade of the Polish dairy sector). Zeszyty Naukowe SGGWw Warszawie. Problemy Rolnictwa Światowego $15(1), 7-20$.

Czyżewski, A., Guth, M. (2016). Zróżnicowanie produkcji mleka w makroregionach Unii Europejskiej z wyróżnieniem Polski (Diversification of milk production in macro-regions of the European Union with the distinction of Poland). PWN, Warszawa.

Czyżewski, B., Śmigla, M. (2012). Instytucjonalne przesłanki rozwoju gospodarstw mleczarskich w Polsce (Institutional conditions for development of dairy farms in Poland). Journal of Agribusiness and Rural Development 3(25), 81-99.

Eurostat (2017). Production and utylization of milk on the farm - annual data. Pobrano z: www.europa.eu/eurostat/web/agriculture/data/database.

FAO Food Index Price. Pobrano 24.08.2018 z: http://www.fao.org/worldfoodsituation/foodpricesindex/en/.

Hałka, A., Leszczyńska, A. (2011). Wady i zalety wskaźnika cen towarów i usług konsumpcyjnych - szacunki obciążenia dla Polski. (The strengths and weaknesses of the consumer price index: estimates of the measurement bias for Poland). Gospodarka Narodowa 9/241, 51-75.

Huettel, S., Jongeneel, R. (2011). How has the EU milk quota affected patterns of herd-size change?, European Review of Agricultural Economics 38, 497-527.

Kasztelan P., (2010). Rozwój gospodarstw mlecznych w warunkach kwotowania produkcji (Development of dairy farms under the condition of milk quota). Roczniki Nauk Rolniczych, Seria G, 97(1), 43-52.

Olszewska, M. (2015). Produkcja mleka w Polsce na tle świata i krajów UE (Milk production In Poland In relation to the world and European Union). Wiadomości Zootechniczne 53(3), 150-157.

Parzonko, A. (2013). Konkurencyjność kosztowa polskich gospodarstw mlecznych na arenie europejskiej w perspektywie zmian polityki rolnej UE po 2014 roku (Competitiveness of Polish dairy farms in the European arena against changes in EU agricultural policy after 2014). Zeszyty Naukowe SGGW w Warszawie. Problemy Rolnictwa Światowego 28(3), 192-202.

Parzonko, A. (2013b). Regionalna zróżnicowanie produkcji mleka w Polsce-uwarunkowania przyrodnicze i ekonomiczne (Regional differences in milk production in Poland-natural and economic determinants). Roczniki Naukowe SERiA 15(2), 265-270.

Parzonko, A. (2016). Polscy producenci mleka na tle Europy (Polish milk producers against the background of Europe). Top Agrar Polska 7, 4-9.

Pietrzak, M., Szajner, P. (2006). Przetwórstwo, handel i spożycie mleka i produktów mlecznych w Polsce w latach 2003-2005 oraz prognozowane kierunki zmian. Roczniki Nauk Rolniczych, Seria G, 93(1), 92-101.

Produkcja mleka i pogłowie krów w Unii Europejskiej (Milk production and cow population in the European Union). Pobrano 24.08.2018 z: http://nowypn.pl/index.php/aktualności/12508-produkcja-mleka.

Rembeza, J., Seremak-Bulge, J. (2009). Ewolucja podstawowych rynków rolnych i jej wpływ na transmisję cen w latach 1990-2008, Program Wieloletni 2005-2009 (The evolution of basic agricultural markets and its impact on the transmission of prices in the years 1990-2008, Multiannual Program 2005-2009), nr 131, Warszawa IERiGŻ-PIB.

Rynek mleka stan i perspektywy (2016). (Milk market. State and perspectives). IERiGŻ-PIB, Warszawa. 
Rynek mleka stan i perspektywy (2017). (Milk market. State and perspectives). IERiGŻ-PIB, Warszawa

Samuelson, P.A., Nordhaus, W.D. (1996). Ekonomia (Economics), PWN, Warszawa

Seremak-Bulge, J. (2015). Rynek mleka stan i perspektywy (Development of milk market state and perspectives). Zakład Badań Rynkowych IERiGŻ-PIB, Warszawa.

Seremak-Bulge, J., Szajner, P., Świetlik, K., Hryszko, K., Rembeza, J., Pieniążek, K. (2005). Rozwój rynku mleczarskiego i zmiany jego funkcjonowania w latach 1990-2005 (Development of the dairy market and changes in its functioning in the years 1990-2005). Program Wieloletni 2005-2009, nr 2, Warszawa IERiGŻ-PIB.

Seremak-Bulge, J., Bodył, M. (2014). Spożycie mleka w Polsce na tle innych krajów (Consumption of milk in Poland compared to other countries). Zagadnienia Ekonomiki Rolnej 1, 146-158.

Sobczyk, M., (2005). Statystyka (Statistics). PWN, Warszawa.

Stańko, S., Mikuła A., (2018). Tendencje na rynku mleka na świecie i w Polsce w latach 2000-2016 (Tendencies in the Word milk market and in Poland in the years 2000-2016), Zeszyty Naukowe SGGW w Warszawie Problemy Rolnictwa Światowego 18(1), 235-247.

Szajner, P. (2017a). Transmisja cen na rynku mleka w Polsce w latach 2004-2017 (Price transmission on milk market in Poland between 2004 and 2017). Zagadnienia Ekonomiki Rolnej 4(353), 3-23.

Szajner, P. (2017b). Wahania koniunkturalne na światowym i polskim rynku odtluszczonego mleka w proszku w latach 2004-2016 (Cyclical Changes of Situation on the World and Domestic Markets of Skimmed Milk Powder In the years 2004-2016), Zeszyty Naukowe SGGW w Warszawie, Problemy Rolnictwa Światowego 17(1), 206-215.

Urban, R. (2004). Przemiany przemysłu spożywczego w latach 1988-2003 (Transformation of the food industry in 1988-2003). Studia i Monografia nr 121, Warszawa IERiGŻ.

Wasilewski, Z. (2009). Stan obecny i kierunki gospodarowania na użytkach zielonych zgodne z wymogami wspólnej polityki rolnej (Present status and directions of grassland and management according to the requirements of the Common Agricultural Policy). Woda, Środowisko, Obszary Wiejskie 9(2), 169-184.

Wilkin, J. (2009). Ekonomia polityczna reform Wspólnej Polityki Rolnej (The political economics of the Common Agricultural Policy reform), Gospodarka Narodowa 1-2(209-210), 1-25.

www.credit-agricole.pl. Pobrano 23.08.2018.

Ziętara, W. (2010). Stan i kierunki rozwoju gospodarstw nastawionych na produkcję mleka w Polsce (State of the art and trends in development of dairy farms in Poland). Roczniki Naukowe SERiA 12(3), 432-437.

Ziętara, W. (2007). Ekonomiczne i organizacyjne problem produkcji mleka przy wysokiej wydajności mlecznej (Economic and organization problems dairy production with high milk yield). Roczniki Nauk Rolniczych, Seria $G, 93,27-36$.

Zimmermann, A., Heckelei, T. (2012). Structural change of European dairy farms-a case regional analysis. Journal of Agricultural Economics 63(3), 576-603.

Do cytowania / For citation:

Bórawski P., Zalewski K. (2018). Czynniki kształtujące produkcję mleka w Polsce na tle UE. Problemy Rolnictwa Światowego, 18(3), 36-48; DOI: 10.22630/PRS.2018.18.3.64

Bórawski P., Zalewski K. (2018). Factors Shaping Milk Production in Poland vis-à-vis the European Union (in Polish). Problems of World Agriculture, 18(3), 36-48; DOI: 10.22630/PRS.2018.18.3.64 